\title{
Effects of an outpatient education program in patients with uncontrolled asthma*
}

\author{
Efeitos de um programa educativo ambulatorial em \\ pacientes com asma não controlada
}

\author{
Carmen Denise Borba Rodrigues, Rosemary Petrik Pereira, Paulo de Tarso Roth Dalcin
}

\begin{abstract}
Objective: To evaluate the effects of an outpatient education program in patients with uncontrolled asthma. Methods: This was an uncontrolled study evaluating an educational intervention and involving patients with uncontrolled asthma $\geq 14$ years of age. The participants completed a questionnaire designed to assess the level of asthma control, the inhalation technique, and quality of life. All of the patients underwent pulmonary function testing, after which they participated in an education program consisting of one 45-min face-to-face session, followed by phone interviews at two, four, and eight weeks. The participants were reevaluated after three months. Results: Sixty-three patients completed the study. There was a significant improvement in the level of asthma control ( $\mathrm{p}<0.001)$. Of the 63 patients, $28(44.4 \%)$ and $6(9.5 \%)$ were classified as having partially controlled asthma and controlled asthma, respectively. The mean FEV was $63.0 \pm 20.0 \%$ and 68.5 $\pm 21.2 \%$ of the predicted value prior to and after the educational intervention, respectively $(p=0.002)$, and all of the quality of life scores improved ( $p<0.05$ for all). The same was true for the proportion of patients prior to and after the educational intervention using the proper inhalation technique when using metered dose inhalers ( $15.4 \%$ vs. $46.2 \% ; p=0.02)$ and dry powder inhalers $(21.3 \%$ vs. $76.6 \% ; p<0.001)$. The logistic regression analysis revealed that an incorrect inhalation technique identified during the first evaluation was independently associated with a favorable response to the educational intervention. Conclusions: This study suggests that an outpatient education program for asthma patients improves the level of asthma control, lung function parameters, and quality of life. An incorrect inhalation technique identified during the first evaluation was predictive of a favorable response to the educational intervention.
\end{abstract}

Keywords: Asthma/prevention and control; Quality of life; Respiratory function tests; Ambulatory care; Health education.

\section{Resumo}

Objetivo: Avaliar os efeitos de um programa educativo ambulatorial em pacientes com asma não controlada. Métodos: Estudo não controlado, avaliando uma intervenção educacional e envolvendo pacientes com idade $\geq 14$ anos com asma não controlada. Os participantes responderam a um questionário para avaliar o grau de controle da asma, a qualidade de vida e a técnica inalatória e foram submetidos a testes de função pulmonar. A seguir, participaram do programa educativo, que consistia de uma sessão inicial de 45 min e de entrevistas telefônicas em duas, quatro e oito semanas. Os participantes foram reavaliados após três meses. Resultados: Completaram o estudo 63 pacientes. Houve melhora significativa no grau de controle da asma $(p<0,001)$. Dos 63 pacientes, $28(44,4 \%)$ e $6(9,5 \%)$ passaram a apresentar asma parcialmente controlada e controlada, respectivamente. Antes e depois a intervenção educacional, a média de VEF foi, respectivamente, $63,0 \pm 20,0 \%$ do previsto e $68,5 \pm 21,2 \%$ do previsto $(p=0,002)$, e todos os escores de qualidade de vida melhoraram ( $p$ $<0,05$ para todos). 0 mesmo ocorreu com a proporção de pacientes com técnica inalatória adequada no uso de inalador pressurizado $(15,4 \%$ vs. $46,2 \% ; p=0,02)$ e de dispositivo de pó $(21,3 \%$ vs. $76,6 \% ; p<0,001)$. A análise de regressão logística identificou que a técnica inalatória incorreta na primeira avaliação estava independentemente associada com a resposta favorável à intervenção educativa. Conclusões: Este estudo sugere que um programa educativo ambulatorial resultou em uma melhora no grau de controle da asma, na função pulmonar e na qualidade de vida. A técnica inalatória incorreta na avaliação inicial foi preditora da resposta favorável à intervenção educativa.

Descritores: Asma/prevenção e controle; Qualidade de vida; Testes de função respiratória; Assistência ambulatorial; Educação em saúde.

* Study carried out in the Department of Pulmonology, Porto Alegre Hospital de Clínicas, Federal University of Rio Grande do Sul School of Medicine, Porto Alegre, Brazil.

Correspondence to: Paulo de Tarso Roth Dalcin. Rua Honório Silveira Dias, 1529/901, São João, CEP 90540-070, Porto Alegre, RS, Brasil. Tel. 5551 3330-0521. E-mail: pdalcin@terra.com.br

Financial support: This study received financial support from the Fundo de Incentivo à Pesquisa do Hospital de Clínicas de Porto Alegre (FIPE-HCPA, Research Incentive Fund of the Porto Alegre Hospital de Clinicas).

Submitted: 16 November 2012. Accepted, after review: 14 February 2013. 


\section{Introduction}

Asthma is one of the most common chronic conditions, as well as being a global health problem. ${ }^{(1)}$ In Brazil, it is estimated that there are approximately 20 million individuals with asthma. ${ }^{(2)}$

The goal of asthma management is to achieve and maintain disease control. ${ }^{(3)}$ However, despite the implementation of guidelines for asthma management around the world and the availability of highly effective drugs for controlling symptoms and for treating the underlying inflammatory process, asthma remains a poorly controlled disease. ${ }^{(4)}$ The lack of disease control might be due to the fact that patients are being prescribed inappropriate medications or that they are using the prescribed medications incorrectly. In addition, asthma severity and comorbidities, such as gastroesophageal reflux, obesity, and smoking, can affect the level of asthma control. ${ }^{(5)}$

In addition to prescription and provision of pharmacological treatment that is appropriate to the level of asthma severity, education and guidance on asthma self-management have recently become recognized as aspects that must also be addressed within their clinical context. ${ }^{(1)}$ Various types of asthma education programs have been developed. Such programs differ in terms of approach, treatment setting, and outcomes of interest. ${ }^{(6-17)}$ The need to adapt this knowledge about asthma education to clinical practice and to make it accessible at public outpatient clinics specializing in asthma motivated a study to evaluate the impact of an individualized educational intervention on disease management.

The objective of the present study was to evaluate the effects of an individualized outpatient education program in patients with uncontrolled asthma.

\section{Methods}

This was a prospective uncontrolled study using a two-phase (prior to and after an educational intervention) comparison of variables. All patients who met the inclusion criteria and agreed to participate were studied sequentially.

The study protocol was approved by the Research Ethics Committee of the Hospital de Clínicas de Porto Alegre (HCPA, Porto Alegre Hospital de Clínicas-Process no. 08553). Written informed consent was obtained from all patients or their legal guardians, in the case of those under 18 years of age.

The study population comprised patients treated at the Pulmonology Department outpatient clinics of the HCPA, which is located in the city of Porto Alegre, Brazil. We included patients aged 14 years or older who had been diagnosed with asthma in accordance with either of two sets of consensus criteria, ${ }^{(18,19)}$ had been classified as having uncontrolled asthma in accordance with the Global Initiative for Asthma (GINA) criteria, ${ }^{(19)}$ and had made at least two prior visits to one of the outpatient clinics mentioned above.

The level of asthma control was assessed by using the classification proposed by the 2007 GINA guidelines. ${ }^{(19)}$ Asthma was considered controlled if all of the following characteristics were present: daytime symptoms twice a week or less and no asthma attacks in the last 3 months; no limitation of activities of daily living; no asthma-related nocturnal symptoms or awakenings; rescue medication required twice a week or less; and normal airflow (FEV 1 and PEF equal to or greater than $80 \%$ of predicted). Asthma was considered partially controlled if one or two of those characteristics were absent, and it was considered uncontrolled if more than two of those characteristics were absent or if the patient had been admitted to the ER or hospitalized for asthma in the last 12 months. An asthma attack was defined as an exacerbation requiring the use of systemic corticosteroids.

Patients who had been diagnosed with other chronic lung diseases were excluded, as were those who did not complete the steps recommended by the study and those who did not give written informed consent.

The volunteers were interviewed by means of a questionnaire that assessed the following variables: age; gender; race; marital status; level of education; family income; smoking status; comorbidities; form of medication acquisition; regularity of use of asthma medications; type of inhaler used; correctness of inhalation technique; and classification of asthma severity.

The first interview, as well as the initial evaluations and the evaluation at 3 months, was performed by the same rater.

The questionnaire included a checklist for evaluating the patients' handling of the device used for inhaling the corticosteroid, and patients were asked to demonstrate their inhalation technique, 
using placebo. For metered dose inhalers, patients were evaluated on the correctness of the following steps: a) shaking the inhaler before using it; b) exhaling normally before using the inhaler; c) holding the inhaler at an appropriate distance $(3-5 \mathrm{~cm})$ from the lips if a spacer is not used or, if a spacer is used, placing the inhaler in the mouth and creating an adequate seal with the lips; d) inhaling slowly and deeply after squeezing the inhaler; and e) performing a breath-hold of at least 10 seconds (after inhalation). For dry powder inhalers, patients were evaluated on the correctness of the following steps: a) exhaling normally before using the inhaler; b) placing the inhaler in the mouth and creating an adequate seal with the lips; c) inhaling as forcefully and deeply as possible; and d) performing a breathhold of at least 10 seconds (after inhalation). The patients' inhalation technique for each type of device was considered correct only if all the steps were properly performed.

Asthma severity was classified on the basis of the daily medication regimen in use, as proposed by the 2002 GINA guidelines. ${ }^{(20)}$

Pulmonary function was assessed, with the use of a computerized spirometer (Jaeger-v4.31; Jaeger, Würzburg, Germany), at the initial interview and 3 months later. We recorded FVC, FEV , and the $\mathrm{FEV}_{1} / \mathrm{FVC}$ ratio. All parameters are expressed as absolute values or as a percentage of predicted values for age, gender, and height. ${ }^{(21)}$

We measured PEF using a portable peak flow monitor (Vitalograph; Boehringer Ingelheim, Ingelheim am Rhein, Germany). The results are expressed as absolute values or as a percentage of predicted values for age, gender, and height. ${ }^{(22)}$

Quality of life was assessed by using a specific questionnaire-the Asthma Quality of Life Questionnaire (AQLQ) ${ }^{(23-26)}$ - which has been translated into Portuguese and validated for use in Brazil. ${ }^{(27)}$ This questionnaire contains 32 questions, grouped into four domains: activity limitation; symptoms; emotional function; and environmental stimuli. The AQLQ can be administered by an interviewer, or it can be selfadministered. The total score of the questionnaire is the arithmetic mean of all items, the minimum score being 1 and the maximum score being 7 . Higher scores mean better asthma-related quality of life. The minimum significant change in score is 0.5 , with a 1-point change being considered moderate and a 1.5-change being considered large. In the present study, the questionnaire was self-administered.

The educational intervention consisted of an initial multistep approach and of phone interviews at 2,4 , and 8 weeks.

The education step was started after an outpatient visit and involved one face-to-face session of approximately $45 \mathrm{~min}$, delivered by the research team's physical therapist. The session followed a structured schedule that included verbal and written instruction and addressed the following points: what asthma is and what its symptoms are; environmental control and how to avoid asthma triggers; the importance of inhaled corticosteroids, as well as of combined inhaled corticosteroids and long-acting $\beta_{2}$ agonists, for preventive disease management; how to obtain asthma medications via the public health care system and how to overcome the limitations; inhalation technique assessment and correction of any errors found; the need for using a spacer when inhaled corticosteroids are delivered by a metered dose inhaler; and clarification and additional instruction as needed.

The education step was followed by $30-\mathrm{min}$ phone interviews at 2, 4, and 8 weeks after inclusion in the study. In each interview, patients were assessed on their level of asthma control; the importance of the use of inhaled corticosteroids was reviewed and reinforced, as were the steps required for correct use; the use of a spacer with a metered dose inhaler was reviewed and stimulated; the level of environmental control was assessed; clarification was provided; and solutions were sought to potential problems.

The participants were reevaluated in a routine visit 3 months after the initial interview.

The primary outcome measure of the study was the proportion of patients who, after the educational intervention, were classified as having controlled asthma or partially controlled asthma. Secondary outcome measures were the quality of life scores and lung function parameters (PEF and $\mathrm{FEV}_{1}$ values).

Effective use of inhaled corticosteroids and long-acting $\beta_{2}$ agonists was defined as selfreported adherence of five days a week or more.

Data were analyzed with the Statistical Package for the Social Sciences, version 18.0 (SPSS Inc., Chicago, IL, USA). Quantitative data are expressed as mean and standard deviation or as median and interquartile range, whereas qualitative 
data are expressed as absolute numbers and percentages. Quantitative data were compared by the t-test for paired samples or by the Wilcoxon matched-pair sign-rank test, whereas qualitative data were analyzed by the chi-square test or by McNemar's test.

The variables gender, race, age, age at asthma diagnosis, level of education (dichotomized into $\leq 9$ years of schooling and $<9$ years of schooling), family income (dichotomized into $\leq 3$ times the national minimum wage and > 3 times the national minimum wage), marital status (dichotomized into married and single/ widowed/separated), asthma severity (dichotomized into severe and mild/moderate), $\mathrm{FEV}_{1}$, inhalation technique (performing all the steps correctly or performing any of the steps incorrectly), type of inhaler (metered dose inhaler or dry powder inhaler), and form of medication acquisition (fully on the patient or fully on public funds) were included individually in a binary logistic regression model (enter method) in order to identify characteristics predictive of a favorable response to the educational intervention. A favorable response was defined as a change in classification to that of controlled asthma or partially controlled asthma after the educational intervention. An unfavorable response was defined as no change in the classification of uncontrolled asthma after the educational intervention. Variables with significance at 0.1 or less, adjusted for gender and age, were included in the multivariate binary logistic regression model (enter method) for predictors of a favorable response.

All statistical tests were two-tailed. The level of significance was set at 5\%.

The sample size was calculated by using PASS 2005: Power Analysis and Sample Size software (NCSS, Kaysville, UT, USA), considering the proportion of patients who, after the educational intervention, would be classified as having controlled asthma or partially controlled asthma. The proportion value for testing the alternative hypothesis was fixed at 0.25 , whereas that for testing the null hypothesis was fixed at 0.05. Assuming an alpha value of 0.05 and a power of $80 \%$, we estimated that it would be necessary to study at least 63 patients.

\section{Results}

Between March of 2009 and March of 2011, 79 patients with uncontrolled asthma were evaluated.
Of those, 5 declined to participate in the study, 10 withdrew from the study after the first evaluation (did not report for reevaluation at 3 months), and 1 was excluded for having COPD. Therefore, 63 patients completed the study.

Table 1 shows the general characteristics of the patients. Of the 63 patients, 53 (84.1\%) were female and $48(76.2 \%)$ were White. The mean age of the individuals was $49.3 \pm 14.1$ years, and the median age at asthma diagnosis was 20.0 years.

Fifty-five patients $(87.3 \%)$ presented with at least one comorbidity, whereas 31 patients $(49.2 \%)$ were obese (body mass index $\geq 30 \mathrm{~kg} /$ $\left.\mathrm{m}^{2}\right), 21$ (33.3\%) had cardiovascular disease, and $19(30.2 \%)$ had gastroesophageal reflux.

Table 2 shows the level of asthma control and lung function results prior to and after the educational intervention. After the intervention, there was a significant improvement in the level of asthma control $(p<0.001)$. Of the 63 patients, $28(44.4 \%)$ were classified as having partially controlled asthma, and 6 (9.5\%) were classified as having controlled asthma, whereas 29 (46\%) continued to be classified as having uncontrolled asthma. There was significant reduction in the proportion of patients who were treated in the emergency room for asthma exacerbation prior to and after the intervention ( $50.8 \%$ vs. $25.4 \% ; p=$ 0.007). There was a significant improvement for the following variables: PEF, in \% of predicted $(\mathrm{p}=0.019)$; FVC, in L $(\mathrm{p}=0.031)$; FVC, in $\%$ predicted $(\mathrm{p}=0.024) ; \mathrm{FEV}_{1}$, in $\mathrm{L}(\mathrm{p}=0.003)$; $\mathrm{FEV}_{1}$, in $\%$ of predicted $(\mathrm{p}=0.002)$; and $\mathrm{FEV}_{1}$ l FVC ratio, in $\%$ of predicted $(p=0.07)$. However, the change in $\mathrm{FEV}_{1}$ was less than $200 \mathrm{~mL}$ and than $12 \%$.

Table 3 shows data on medication acquisition, asthma medication use, and inhalation technique prior to and after the educational intervention. There were no significant differences for the proportion of patients who obtained the medications with their own funds $(p=1.00)$, for the proportion of patients who obtained the medications via the health care clinic $(p=0.549)$, or for the proportion of patients who obtained the medications via the State Department of Health $(p=1.00)$. There was also no significant change in effective use of medications containing inhaled corticosteroids $(p=0.18)$ or of medications containing long-acting $\beta_{2}$ agonists $(p=1.00)$. The proportion of patients who performed all 
the steps of the inhalation technique correctly increased significantly from $15.4 \%$ to $46.2 \%$ (p $=0.021$ ) among those who used metered dose

Table 1 - General characteristics of the 63 patients with uncontrolled asthma included in the study. ${ }^{\text {a }}$

\begin{tabular}{|c|c|}
\hline Variables & Values \\
\hline \multicolumn{2}{|l|}{ Gender } \\
\hline Male & $10(15.9)$ \\
\hline Female & $53(84.1)$ \\
\hline \multicolumn{2}{|l|}{ Race } \\
\hline White & $48(76.2)$ \\
\hline Non-White & $15(23.8)$ \\
\hline Age, years ${ }^{\mathrm{b}}$ & $49.3 \pm 14.1$ \\
\hline Age at diagnosis, years ${ }^{c}$ & $20.0(34.0)$ \\
\hline \multicolumn{2}{|l|}{ Level of education } \\
\hline 9 years of schooling & $41(65.1)$ \\
\hline High school & $16(25.4)$ \\
\hline College & $6(9.5)$ \\
\hline \multicolumn{2}{|c|}{$\begin{array}{l}\text { Family income, number of times the } \\
\text { national minimum wage }\end{array}$} \\
\hline$\leq 3$ & $58(92.1)$ \\
\hline $4-10$ & $4(6.3)$ \\
\hline$>10$ & $1(1.6)$ \\
\hline \multicolumn{2}{|l|}{ Asthma severity } \\
\hline Mild persistent & $2(3.2)$ \\
\hline Moderate persistent & $10(15.9)$ \\
\hline Severe persistent & $51(81.0)$ \\
\hline \multicolumn{2}{|l|}{ Smoking status } \\
\hline Never smoker & $47(74.6)$ \\
\hline Current smoker & $0(0)$ \\
\hline Former smoker & $16(25.4)$ \\
\hline
\end{tabular}

Values expressed as $\mathrm{n}(\%)$, except where otherwise indicated ${ }^{b}$ Values expressed as mean \pm SD. ${ }^{c}$ Values expressed as median (interquartile range). inhalers and from 21.3\% to 76.6\% ( $p<0.001)$ among those who used dry powder inhalers. The proportion of patients who used a spacer with their metered dose inhaler increased significantly from $36 \%$ to $68 \%(p=0.021)$.

Table 4 shows quality of life assessment data prior to and after the educational intervention. The AQLQ total score and domain scores improved significantly $(p<0.001$ for all).

In the binary logistic regression to identify predictors of a favorable response to the educational intervention, age, \% predicted $\mathrm{FEV}_{1}$, and inhalation technique reached a significance of $p<0.1$. These variables were included in the multivariate binary logistic regression model, adjusted for gender and age. Table 5 shows the results of this analysis. An incorrect inhalation technique was independently associated with a favorable response to the educational intervention $(p=0.005)$.

\section{Discussion}

In the present study, we observed that an individualized outpatient education program for patients with uncontrolled asthma had a positive effect on the level of asthma control in a clinical follow-up of 3 months. Of the 63 patients with uncontrolled asthma studied, 28 (44.4\%) were reclassified as having partially controlled asthma and $6(9.5 \%)$ were reclassified as having controlled asthma. Secondarily, there was improvement in lung function parameters (although it did not reach the minimum clinically significant change) and in all AQLQ domains. ${ }^{(23,24)}$ The proportion

Table 2 - Level of asthma control and pulmonary function results prior to and after the educational intervention. ${ }^{2}$

\begin{tabular}{|c|c|c|c|}
\hline Variables & Pre-intervention & Post-intervention & $\mathrm{p}$ \\
\hline \multicolumn{4}{|l|}{ Level of asthma control } \\
\hline Controlled & $0.0(0.0)$ & $6(9.5)$ & $<0.001$ \\
\hline Partially controlled & $0.0(0.0)$ & $28(44.4)$ & \\
\hline Uncontrolled & $63(100.0)$ & $29(46.0)$ & \\
\hline Emergency room visit for asthma & $32(50.8)$ & $16(25.4)$ & 0.007 \\
\hline \multicolumn{4}{|l|}{ Pulmonary function ${ }^{b}$} \\
\hline $\mathrm{PEF}, \mathrm{L} / \mathrm{min}$ & $229.7 \pm 102.1$ & $248.4 \pm 96.4$ & 0.053 \\
\hline PEF, \% of predicted & $47.5 \pm 19.8$ & $52.5 \pm 20.3$ & 0.019 \\
\hline FVC, L & $2.57 \pm 0.90$ & $2.70 \pm 0.90$ & 0.031 \\
\hline FVC, \% of predicted & $79.7 \pm 19.0$ & $83.7 \pm 19.7$ & 0.024 \\
\hline $\mathrm{FEV}_{1}, \mathrm{~L}$ & $1.68 \pm 0.70$ & $1.83 \pm 0.80$ & 0.003 \\
\hline $\mathrm{FEV}_{1}, \%$ of predicted & $63.0 \pm 20.0$ & $68.5 \pm 21.2$ & 0.002 \\
\hline $\mathrm{FEV}_{1} / \mathrm{FVC}, \%$ & $0.64 \pm 0.12$ & $0.66 \pm 0.11$ & 0.086 \\
\hline $\mathrm{FEV}_{1} / \mathrm{FVC}, \%$ of predicted & $0.78 \pm 0.14$ & $0.81 \pm 0.13$ & 0.07 \\
\hline
\end{tabular}

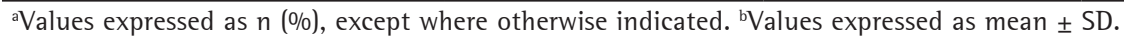


Table 3 - Form of medication acquisition, asthma medication use, and inhalation technique prior to and after the educational intervention. ${ }^{\text {a }}$

\begin{tabular}{|c|c|c|c|}
\hline Variables & Pre-intervention & Post-intervention & $\mathrm{p}$ \\
\hline \multicolumn{4}{|l|}{ Form of medication acquisition } \\
\hline Fully on the patient & $40(63.5)$ & $40(63.5)$ & 1.00 \\
\hline Fully on the Health care clinic & $40(63.5 \%)$ & 37 (38.7) & 0.549 \\
\hline Fully on the State Department of Health & $5(7.9)$ & $5(7.9)$ & 1.00 \\
\hline \multicolumn{4}{|l|}{ Effective use of the medications } \\
\hline Inhaled corticosteroids & $55(87.3)$ & $60(95.2)$ & 0.180 \\
\hline Short-acting $\beta_{2}$ agonists & $42(66.7)$ & $43(68.3)$ & 1.00 \\
\hline \multicolumn{4}{|l|}{ Type of inhaler, $n(\%)$} \\
\hline Metered dose inhaler & $31(49.2)$ & $28(44.4)$ & 0.375 \\
\hline Dry powder inhaler & $32(50.8)$ & $35(55.6)$ & \\
\hline \multicolumn{4}{|l|}{ Inhalation technique, n (\%) } \\
\hline \multicolumn{4}{|l|}{ Metered dose inhaler } \\
\hline Correct & $4(15.4)$ & $12(46.2)$ & 0.021 \\
\hline Incorrect & $22(84.6)$ & $14(53.8)$ & \\
\hline \multicolumn{4}{|l|}{ Dry powder inhaler } \\
\hline Correct & $10(21.3)$ & $36(76.6)$ & $<0.001$ \\
\hline Incorrect & 37 (78.7) & $11(23.4)$ & \\
\hline Use of a spacer with a metered dose inhaler & $9(36)$ & $17(68)$ & 0.021 \\
\hline
\end{tabular}

${ }^{a}$ Values expressed as $n(\%)$.

Table 4 - Quality of life assessment by means of the Asthma Quality of Life Questionnaire prior to and after the educational intervention.

\begin{tabular}{lccc}
\hline \multicolumn{1}{c}{ AQLQ } & Pre-intervention & Post-intervention & $\mathrm{p}$ \\
\hline Activity limitation & $3.2(1.6)$ & $4.3(2.3)$ & $<0.001$ \\
Symptoms & $3.4(1.8$ & $5.0(3.2)$ & $<0.001$ \\
Emotional function & $2.8(2.8)$ & $4.0(3.6)$ & $<0.001$ \\
Environmental stimuli & $2.5(2.5)$ & $4.3(3.8)$ & $<0.001$ \\
Total score & $3.2(1.5)$ & $4.5(2.6)$ & $<0.001$ \\
\hline
\end{tabular}

AQLQ: Asthma Quality of Life Questionnaire.

Table 5 - Multivariate binary logistic regression (enter method) for predictors of a favorable response to the educational intervention. ${ }^{\mathrm{a}}$

\begin{tabular}{lcccc}
\hline \multicolumn{1}{c}{ Variable } & $\beta$ & $\mathrm{p}$ & OR & $95 \% \mathrm{Cl}$ \\
\hline Gender & -0.213 & 0.804 & 0.808 & $0.150-4.346$ \\
Age & 0.029 & 0.201 & 1.029 & $0.985-1.076$ \\
FEV $_{1}$ & -0.021 & 0.160 & 0.979 & $0.952-1.008$ \\
Inhalation technique & 1.720 & 0.005 & 5.583 & $1.699-18.343$ \\
Constant & -0.975 & 0.561 & 0.377 & - \\
\hline
\end{tabular}

${ }^{\mathrm{a} A}$ favorable response was defined as a change in classification to that of controlled asthma or partially controlled asthma after the educational intervention.

of patients who performed all the steps of the inhalation technique correctly increased from $15.4 \%$ to $46.2 \%$ among those who used metered dose inhalers and from $21.3 \%$ to $76.6 \%$ among those who used dry powder inhalers. Among the patients who used dry powder inhalers, the educational intervention resulted in an increase in the proportion of those who used a spacer from $36 \%$ to $68 \%$. An incorrect inhalation technique identified during the first evaluation was independently associated with a favorable response to the educational intervention.

One of the educational focuses of the present study was to highlight the importance of inhaled 
corticosteroids, as well as of combined inhaled corticosteroids and long-acting $\beta_{2}$ agonists, for preventive disease management, with an emphasis on adherence. However, the proportion of patients who reported effective use ( $\geq$ five days a week) of inhaled corticosteroids and longacting $\beta_{2}$ agonists did not increase. In contrast, a previous study ${ }^{(10)}$ showed that a short-term educational intervention involving 174 asthma patients resulted in a significant increase in the use of inhaled corticosteroids. The difference is probably due to the fact that the present study included patients with greater disease severity, all of whom had uncontrolled asthma.

At the time of the study, not all medications for the maintenance treatment of asthma were available via the public health care system in the state of Rio Grande do Sul. Beclomethasone dipropionate and short-acting $\beta_{2}$ agonist bronchodilators for use in metered dose inhalers were available in primary health care facilities in most cities. However, long-acting $\beta_{2}$ agonists (formoterol and salmeterol), as well as the combination of inhaled corticosteroids and longacting $\beta_{2}$ agonists, were available for free to only a minority of these patients. In the present study, the educational intervention included explanations of the administrative procedures involved in obtaining medications via the public health care system. Nevertheless, the intervention did not result in an increase in the proportion of patients who obtained the medications via the public health care system.

The efficacy of asthma treatment depends also on the patient's ability to perform the inhalation technique correctly. Other studies have also shown that education has a significant impact on the proportion of patients who use inhalers correctly. ${ }^{(6,11,15)}$ The present study, by demonstrating that an incorrect inhalation technique is an independent predictor of response to the educational intervention, contributes an important finding.

In Brazil, other studies have addressed asthma educational interventions. One group of authors ${ }^{(28)}$ evaluated the impact of a five-day educational camp program for children with asthma, reporting a positive impact on knowledge and improvement in asthma management skills. Another group of authors ${ }^{(10)}$ evaluated the effects of a short-term individualized asthma education program on treatment adherence, inhalation techniques, and disease control, finding improvement in the use of medications for asthma control and a decrease in the number of emergency room visits. Another study ${ }^{(6)}$ reported increased knowledge about the disease and clinical improvement in patients with moderate or severe persistent asthma after they had participated in an education program delivered during routine outpatient visits, over a 2-year period.

The major limitation of the present study is related to its uncontrolled design. The fact that this was not a randomized clinical trial, without parallel monitoring of a control group not receiving the intervention, prevents us from stating definitely that the impact observed on the factors studied is attributable exclusively to the educational intervention and not to other treatment components. Another aspect is that the medication for the treatment of asthma was not made widely available to all patients for free. Therefore, difficulties in obtaining the medication might have lessened the impact of the intervention.

In conclusion, the present study suggests that an individualized outpatient education program has positive effects on the level of asthma control, with improvement in lung function parameters and in quality of life scores. An incorrect inhalation technique identified during the first evaluation was predictive of a favorable response to the educational intervention.

\section{References}

1. Global Initiative for Asthma. Global strategy for asthma management and prevention. Bethesda: National Institutes of Health, National Heart, Lung, and Blood Institute; 2011.

2. Sociedade Brasileira de Pneumologia e Tisiologia. Diretrizes da Sociedade Brasileira de Pneumologia e Tisiologia para o Manejo da Asma - 2012. J Bras Pneumol. 2012;38(Suppl 1):S1-S46.

3. Schatz M, Zeiger RS, Vollmer WM, Mosen D, Cook EF. Determinants of future long-term asthma control. J Allergy Clin Immunol. 2006;118(5):1048-53. http:// dx.doi.org/10.1016/j.jaci.2006.07.057 PMid:17088128

4. Cazzoletti L, Marcon A, Janson C, Corsico A, Jarvis D, Pin 1, et al. Asthma control in Europe: a real-world evaluation based on an international population-based study. J Allergy Clin Immunol. 2007;120(6):1360-7. http:// dx.doi.org/10.1016/j.jaci.2007.09.019 PMid:17981317

5. Barnes PJ. The size of the problem of managing asthma. Respir Med. 2004;98 Suppl B:S4-8.

6. Angelini L, Robles-Ribeiro PG, Carvalho-Pinto RM, Ribeiro M, Cukier A, Stelmach R. Two-year evaluation of an educational program for adult outpatients with asthma. J Bras Pneumol. 2009;35(7):618-27. PMid:19668999

7. Bailey WC, Kohler CL, Richards JM Jr, Windsor RA, Brooks CM, Gerald LB, et al. Asthma self-management: 
do patient education programs always have an impact? Arch Intern Med. 1999;159(20):2422-8. http://dx.doi. org/10.1001/archinte.159.20.2422 PMid:10665890

8. Castro M, Zimmermann NA, Crocker S, Bradley J, Leven C, Schechtman KB. Asthma intervention program prevents readmissions in high healthcare users. Am J Respir Crit Care Med. 2003;168(9):1095-9. http://dx.doi.org/10.1164/ rccm.200208-8770C PMid:12807696

9. Côté J, Bowie DM, Robichaud P, Parent JG, Battisti L, Boulet LP. Evaluation of two different educational interventions for adult patients consulting with an acute asthma exacerbation. Am J Respir Crit Care Med. 2001;163(6):1415-9. http://dx.doi.org/10.1164/ ajrccm.163.6.2006069 PMid:11371411

10. Dalcin Pde T, Grutcki DM, Laporte PP, Lima PB, Viana VP, Konzen GL, et al. Impact of a short-term educational intervention on adherence to asthma treatment and on asthma control. J Bras Pneumol. 2011;37(1):19-27. PMid:21390428

11. de Oliveira MA, Faresin SM, Bruno VF, de Bittencourt AR, Fernandes AL. Evaluation of an educational programme for socially deprived asthma patients. Eur Respir J. 1999;14(4):908-14. http://dx.doi.org/10.1034/j.13993003.1999.14d30.x PMid:10573241

12. Ignacio-García JM, Pinto-Tenorio M, Chocrón-Giraldez MJ, Cabello-Rueda F, López-Cozar Gil Al, lgnacio-García JM, et al. Benefits at 3 yrs of an asthma education programme coupled with regular reinforcement. Eur Respir J. 2002;20(5):1095-101. http://dx.doi.org/10.1 183/09031936.02.00016102 PMid:12449160

13. Janson SL, McGrath KW, Covington JK, Cheng SC, Boushey HA. Individualized asthma self-management improves medication adherence and markers of asthma control. J Allergy Clin Immunol. 2009;123(4):840-6. http:// dx.doi.org/10.1016/j.jaci.2009.01.053 PMid:19348923 PMCid:2729175

14. Klein JJ, van der Palen J, Uil SM, Zielhuis GA, Seydel ER, van Herwaarden CL. Benefit from the inclusion of selftreatment guidelines to a self-management programme for adults with asthma. Eur Respir J. 2001;17(3):38694. http://dx.doi.org/10.1183/09031936.01.17303860 PMid:11405516

15. Prabhakaran L, Lim G, Abisheganaden J, Chee CB, Choo YM. Impact of an asthma education programme on patients' knowledge, inhaler technique and compliance to treatment. Singapore Med J. 2006;47(3):225-31. PMid:16518558

16. Put C, van den Bergh O, Lemaigre V, Demedts M, Verleden G. Evaluation of an individualised asthma programme directed at behavioural change. Eur Respir J. 2003;21(1):109-15. http://dx.doi.org/10.1183/0903 1936.03.00267003 PMid:12570118

17. Yoon R, McKenzie DK, Bauman A, Miles DA. Controlled trial evaluation of an asthma education programme for adults. Thorax. 1993;48(11):1110-6. http://dx.doi. org/10.1136/thx.48.11.1110 PMid:8296253 PMCid:464888

18. IV Brazilian Guidelines for the management of asthma [Article in Portuguese]. J Bras Pneumol. 2006;32(Suppl 7):S447-74. PMid:17420905

19. Global Initiative for Asthma. Global strategy for asthma management and prevention. Bethesda: National Institutes of Health, National Heart, Lung, and Blood Institute; 2007.

20. .Global Initiative for Asthma. Global strategy for asthma management and prevention. Bethesda: National Institutes of Health, National Heart, Lung, and Blood Institute; 2002.

21. Pereira CA, Barreto SP, Simões JG, Pereira FW, Gerstler JG, Nakatani J. Valores de referência para espirometria em uma amostra da população brasileira adulta. J Pneumol. 1992;18(1):10-22.

22. Gregg 1, Nunn AJ. Peak expiratory flow in normal subjects. Br Med J. 1973;3(5874):282-4. http://dx.doi.org/10.1136/ bmj.3.5874.282

23. Juniper EF, Guyatt GH, Epstein RS, Ferrie PJ, Jaeschke R, Hiller TK. Evaluation of impairment of health related quality of life in asthma: development of a questionnaire for use in clinical trials. Thorax. 1992;47(2):76-83. http://dx.doi.org/10.1136/thx.47.2.76 PMid:1549827 PMCid:463574

24. Juniper EF, Guyatt GH, Ferrie PJ, Griffith LE. Measuring quality of life in asthma. Am Rev Respir Dis. 1993;147(4):832-8. http://dx.doi.org/10.1164/ ajrccm/147.4.832 PMid:8466117

25. Juniper EF, Guyatt GH, Willan A, Griffith LE. Determining a minimal important change in a disease-specific Quality of Life Questionnaire. J Clin Epidemiol. 1994;47(1):81-7. http://dx.doi.org/10.1016/0895-4356(94)90036-1

26. Juniper EF, Buist AS, Cox FM, Ferrie PJ, King DR. Validation of a standardized version of the Asthma Quality of Life Questionnaire. Chest. 1999;115(5):1265-70. http:// dx.doi.org/10.1378/chest.115.5.1265 PMid:10334138

27. Corrêa da Silva LM, Corrêa da Silva LC. Validação do questionário de qualidade de vida em asma (Juniper) para o português brasileiro. Revista AMRIGS. 2007;51(1):31-7.

28. Costa Mdo R, Oliveira MA, Santoro lL, Juliano Y, Pinto JR, Fernandes AL. Educational camp for children with asthma. J Bras Pneumol. 2008;34(4):191-5. PMid:18425254

\section{About the authors}

\section{Carmen Denise Borba Rodrigues}

Graduate Student. Graduate Program in Pulmonology, Federal University of Rio Grande do Sul School of Medicine, Porto Alegre, Brazil.

\section{Rosemary Petrik Pereira}

Adjunct Professor. Federal University of Rio Grande do Sul School of Medicine, Porto Alegre, Brazil.

Paulo de Tarso Roth Dalcin

Associate Professor. Federal University of Rio Grande do Sul School of Medicine, Porto Alegre, Brazil. 